\title{
Empirical Assessment of Good Governance in the Public Sector of Malaysia
}

\author{
Maizatul Akmar Khalid \\ Lecturer \\ Kolej Universiti Poly-Tech MARA, Kuala Lumpur \\ Email: maizakmal@gmail.com
}

\author{
Md. Mahmudul Alam* \\ School of Economics, Finance \& Banking, College of Business \\ Universiti Utara Malaysia, Sintok, Kedah Darul Aman, Malaysia. \\ Email: rony000@gmail.com \\ Jamaliah Said \\ Accounting Research Institute, Universiti Teknologi MARA \\ Shah Alam, Selangor, Malaysia \\ Email: jamaliah533@salam.uitm.edu.my \\ * Corresponding author
}

\section{Citation Reference:}

Maizatul, A.K., Alam, M.M., and Said, J. 2016. Empirical Assessment of the Good Governance in the Public Sectors of Malaysia. Economics and Sociology, Vol. 9(4), pp. 289-304. (online) http://www.economicssociology.eu/files/E\&S 94 Khalid Alam Said.pdf

This is a pre-publication copy.

The published article is copyrighted by the publisher of the journal. 


\title{
Empirical Assessment of Good Governance in the Public Sector of Malaysia
}

\begin{abstract}
To improve the trust of citizens and delivery of services, employing good governance principles in the public sector is very crucial. Despite efforts to improve service delivery, criticisms and complains toward public services remain evident. This study aims to assess the status of good governance practices in the public sector of Malaysia. Primary data were collected from the responses of 109 department heads under 24 federal ministries to a survey questionnaire. Respondent perception of good governance practices was measured using a seven-point Likert scale and analyzed by descriptive statistics and path measurement modeling. Standard diagnostic tests were also conducted to check the reliability of the data and model. Results indicated that nine factors were significant in the measurement of good governance practices. However, very few people in the public sector of Malaysia practice fraud control, which is at the lowest intensity. Among the service groups, the engineer group practiced good governance at the highest level, whereas the health service group practiced good governance at the lowest level. Therefore, still there are scopes available to improve good governance systems to become more reliable and efficient public sector in Malaysia. Findings of the study will help policy makers improve the efficiency of the public sector of Malaysia and other countries.
\end{abstract}

Key Words: Public Sector; Good Governance; Path Measurement Model; Factor Analysis; Malaysia

JEL Classification: L20, M10, G30

* Corresponding author

\section{Introduction}

The transformation of Malaysia from a developing country to a developed one is ongoing. Only four years to go before 2020, the year when Malaysia is targeted to become a fully developed nation. Vision 2020 is a program that encourages Malaysia to develop economically, socially, and politically through the enhancement of government systems, social and spiritual aspects, and national satisfaction and confidence (The Malaysian Digest, 2014). Good governance is considered as an important element to achieve Vision 2020. Strategies have been introduced to improve the quality of good governance in the Malaysian public sector, while cultivating integrity across all segments of the country (The New Straits Times Online, 2014). Many reform initiatives have been conducted since 1980s, such as "Clean, Efficient and Trustworthy", "Integration of Islamic Values", "Excellent Work Culture", "Code of Work Ethics", "Client's Charter", and "ISO 9000".

Moreover, the Malaysian Institute of Integrity (MII) was established to cultivate compulsory human capital and knowledge resource within the civil sector (Rusnah et al., 2011). The National Integrity Plan (NIP) aimed to mitigate corruption, misconduct, misuse of power, and improve efficiency and effectiveness of the public delivery system by 2008. In 2009, Malaysia introduced a new approach toward transforming the government and public sector by focusing on six National Key Results Areas (NKRAs) under the Government Transformation Programs with the objective of changing the government machinery to be more effective in its service delivery and be accountable for outcomes that matter most to people as well as to aid the country in becoming an advanced, united, and just society with high standards of living. Administrative reformation to improve government accountability 
and strengthen the public sector was identified as the most important area for the benefit of the people and the progress of nation, as well as a crucial step of the government to maintain public confidence and the determination of the government in implementing good governance in the public sector.

Despite efforts to improve service delivery, criticisms and complaints toward public service remain to be heard. The public sector continues to face criticisms for its inefficiency, red tape, lack of flexibility, ineffective accountability, and poor performance for a long period of time (Siddiquee, 2006). Moreover, Malaysians are still under the impression that the public sector is easily manipulated by malevolent people, and this perception has dampened public confidence in government institutions that allegedly practice corruption in government procurement and in business transfers at the local municipal level and demonstrate land excision abuse and land transfer fraud (The Star, 2008). According to Iyer (2011), poor service delivery reflects gaps in accountability, inequalities in policy planning, and inadequate coordination across public agencies. Furthermore, a number of issues in Malaysia's public sector are on accountability, integrity, and ethical behavior.

These issues had been highlighted prior to 2012 in the report of the Auditor General, including issues on the negligence of public officials who fail to uphold their duty of protecting government interest. Several weaknesses have also been observed during the audit, including improper payment, overlooked specifications or low-quality/unsuitable items in procurement, unreasonable delays, wastage, weaknesses in revenue management, and management of governments assets (National Audit Department, 2013). The report further discussed that the weaknesses are due to the negligence of officers, such as their inability to comply with the rules and regulations, lack of monitoring, lack of project management skills, and failure to attend to the outcome/effect of programs/activities/projects, resulting in the wastage of a significant amount of money.

An example is the case of the Royal Malaysian Customs Department (RMCD) in the procurement of shoes for its personnel, which was managed by its headquarters from 2009 to 2013. By the end of 2012, audit findings revealed that the shoes purchased in 2009 was yet to be distributed at the end of 2012 and that a total of 7,659 pairs of shoes were damaged and must be disposed (National Audit Department, 2013). The mismanaged procurement of the shoes by RMCD has resulted in a significant loss to the government. The matter, which is still under investigation, has incurred a cost to the government and reflected in the coffers of the government as because of the inefficiency and negligence of the officers responsible in procurement or of those responsible in the distribution of the shoes.

Another finding from the report revealed that the lack of control in asset management by the Royal Malaysian Police has led to the acquisition of invaluable assets, such as firearms and handcuffs, by the government. An inefficient integrity system in the management and security of assets could threaten public safety. According to the National Audit Department (2013) from 2010 to 2012, valuable assets were reported missing. From the perspective of the auditor general, the overall management of lost assets by the Royal Malaysian Police was unsatisfactory. This finding has generated concern among the public on the integrity and accountability of public agencies to protect national security, while failing to manage and control assets efficiently.

In terms of project management, the auditors also discovered the highly priced procurement activities of the Ministry of Defense, which were supposed to be conducted by a tendering 
process divided into four quotations. The failure of officers to adhere to treasury instructions has tarnished the image of the ministry and the public sector as a whole. These few cases highlight numerous weaknesses that lead the public to question public sector management of employees and adherence to integrity, responsibility, and accountability in the implementation of good governance.

In Malaysia, the Anti-Corruption Agency was established in 1967 to contain corruption and all kinds of mismanagement in the society. However, the high level of corruption in Malaysia has rendered most of the agency's strategies and campaigns as seemingly insignificant in containing and fighting corruption (Siddiquee, 2009). Moreover, the Asia Pacific Fraud Survey Report Series of 2013 reported that Malaysia, together with China, have the highest levels of bribery and corruption. In addition, the TI Bribe Payers Index Ranking of 2002 presented Malaysia as number 15 out of 21 countries.

The Malaysian government has implemented initiatives in terms of programs and budgets to ensure the efficient management of public money. Measures have also been implemented to monitor the performance of good governance practices in the public sector. Therefore, this study attempts to explore the current level of good governance practices in the public sector of Malaysia. The findings of this study will also help policy makers of other countries in ensuring good governance practices in the public sector.

\section{Literature Review on the Factors of Good Governance}

Governance can be understood as the process of decision making and the process by which decisions are either being implemented or not. Governance can be used in various contexts, such as corporate, international, national, and local governance. The government acts as one of the actors who play a major role in governance, while other actors depend on their position in the government. Good governance has a number of factors that affect quality elements in the public sector (Aziz et al., 2015 a,b,c; Said et al., 2015, 2016). Based on the literature, these elements are described as follows.

\subsection{Strategic Alliance}

Dickson, Phelps, and Waugh (2010) defined alliance as "inter-firm cooperation that falls between the extremes of discrete, short-term agreements and the complete merger between organizations". Meanwhile, Glaister et al., (2003) defined international alliance as a cooperation between firms of different nations. Alliances involve a number of forms, such as joint ventures, equity alliances, non-equity alliances (Li, 2008), merger and acquisitions (Wiklund and Shepherd, 2009), licensing contracts (Baker et al., 2008), and partnerships (Bu"yu"ko"zkan, Feyzioglu and Nebol, 2008).

Firms and institutions often do not keep all the necessary resources and capabilities to compete successfully. However, strategic alliances present an option for these firms and institutions by obtaining opportunities that would otherwise be unobtainable with the firm's existing capabilities. In principle, alliances would allow partner firms to combine resources in the formation of joint competitive advantage (Teng and Das, 2008). Forming a strategic alliance has been recognized as a valuable route for small and medium-sized enterprises (SMEs) for them to achieve a sustainable competitive advantage (Cannatelli, 2012).

Ohame (1989) stated that technology is gradually becoming more complicated because of the enlargement of new key products. The difficulty in monitoring primary resources has 
encouraged businesses to adopt strategic alliances to share basic knowledge and to ensure the production of new research technologies. According to Tie (2004), the lack of strategic alliances between schools, family members, and community representatives leads to the low effectiveness of school programs introduced by the Ministry of Education, which is important in reducing the incidence of violence, gangsterism, vandalism, and misconducts.

\subsection{Strategic Planning}

Strategic planning involves approaches, devices, beliefs, and mindsets for scientific inquiry, consultancy, and policy practice. Strategic planning is used as a good entrepreneurial reminder focused on satisfying clients (Placet and Branch, 2002). Therefore, this should also be the primary focus of public services (Sumpor and Dokic, 2012)

Strategic planning is important in public and private institutions because it establishes practice protocols with the aim of achieving business goals. Moreover, strategic planning is a dynamic, universal, participatory, and collective process used to identify the goals, strategies, and practices of institutions. The process starts with the recognition of barriers in institutions. Instruction for practices are then established for all units to follow to achieve institutional goals (Silva and Neto, 2014). The interdisciplinary approach in the strategic planning process is associated with the sustainable development discourse that clarify the negative and positive effects of certain policies and practices toward other development phases (Sumpor and Dokic, 2013). A previous study also found the lack of efficiency in the strategic plan of the Royal Malaysian Custom (RMC), which results in inconsistencies of RMC practice compared with international practices (Muzainah and Mahamad, 2012)

\subsection{Risk Management}

Risk management is crucial for good governance because the governance framework includes strategic and operational decision making, with the latter depending mostly on the knowledge and understanding of businesses and access to compulsory information via electronic or by other means (Barret, 2007). Good governance guarantees the execution of ethical values, codes, roles, and responsibilities under a clear risk management framework with a welldefined set of accountabilities.

Furthermore, an effective risk management system helps organizations achieve business objectives while improving financial reporting and maintaining reputation (Subramaniam, McManus, and Zhang, 2009). Audit committees focus on the challenge of a comprehensive risk profile and context, whereas internal audit emphasizes on the implementation of effective risk management and on the preservation of objectivity and consistency with its formation. Thus, the effectiveness of risk management is closely related to the integrity and ethical standards of the senior management. Understanding the principles of the organization and applying a formal risk management strategy into strategic decision making is important. Risk management can be an organization's competitive advantage in improving strategic thinking and ethical standards, allowing corporate governance to develop beyond the traditional ground of corporate philanthropy (Demidenko and McNutt, 2010).

\subsection{Audit}

Auditors are a major part of an organization's monitoring system and comprise one of the important factors of corporate governance. Therefore, auditors have to work together with other actors in corporate governance to ensure the generation of high-quality financial reports to stakeholders, while protecting the interests of existing and potential future shareholders and investors (Arnold, 2002). 
Alleyne and Howard (2004) found that organizations with good internal control, auditors, and strong audit committee can cope comprehensively with fraud at any practice. Okpala (2012) revealed that though external auditors have strong positions in an organization, the internal audit committee has an important role in corporate governance. Moreover, results also identified a relationship between audit committee practices and the integrity of financial statements. This relationship strengthens the quality of corporate governance and avoids corporate failure.

According to Ghonkrokta and Lather (2007), social audit is a significant social performance assessment to determine the needs of the society. Boyd (2005) added that social audit is a method of determining the degree to which an institution lives up to its beliefs and objectives. Thus, different organizations and governments have shown interest in implementing social audit to ensure commitment to good governance and sustainable development (Ghonkrokta and Lather, 2007).

\subsection{Fraud Control}

Martinov-Bennie (2007) defined institutional fraud as the intentional practice involving dishonest actions to gain an unjust or illegal benefit. Usually, the effect of a less effective internal control environment has allowed managements to perform such frauds. As cited by Donker and Zahir (2008), recent corporate scandals are mostly plagued by fraud. New regulations and recommendations for corporate governance codes have been introduced with the intention of mitigating fraud cases and future lawsuit cases in the future. Well-governed organizations are less accountable to fraud and lawsuit cases. The International Federation of Accountants (IFAC) has also suggested that organizations must have an independent audit committee that functions independently from the management, has good financial experience, meets frequently, and evaluates the integrity of financial reports. Martinov-Bennie (2007) stated that control environments involving governance and management roles are accountable for prevention and detection of fraud and error.

\subsection{Quality Performance}

Hifzainam (2014) noted that good corporate governance promotes the maintenance of economic development by increasing the performance of companies and enhancing access to external capital from investors and financial institutions. In China and India, for example, good corporate governance supports a number of objectives for developing public policies. Good corporate governance also mitigates exposure to financial crises in countries, promotes property rights, reduces transaction cost and cost of capital, and leads to the development of a capital market. Peda, Argento, and Grossi (2013) showed that the formation and use of the governance devices act are important in determining the trade-off between financial and nonfinancial performance of organizations and of mixed public-private ownership.

Coleman and Osei (2008) postulated that governance is important in determining the performance of MFIs and that the independence of the board and the difference in the position of the CEO and the board chairperson has a positive relationship with performance measures. In addition, governance mechanisms are positively associated with organizational performance (Louizi, 2006).

\subsection{Financial Resourcing}

Companies consist of resources such as financial, physical, human, and organizational resources (Barney, 1991; Colombo and Piva, 2008; Jones and Jayawarna, 2010). These 
resources are improved by linking entrepreneurial endowments, such as funds, experience, time, and contacts, with outside resources obtained as the business becomes recognized (Brush, Manolova and Edelman 2008). Meanwhile, tangible resources, such as property plant and equipment, and intangible resources have also become important to the establishment of new business (Lichtenstein and Brush., 2001).

Thus, Martin, Linda, Joyce, and Max (2007) suggested that a well-planned, thoughtful strategy will help ensure the successful implementation of financial control, while a powerful fraud fighting mechanism is provided for the organization.

\subsection{Human Resource Management}

Siddiquee (2006) noted that governance can be considered a tool for improving public administration drafting laws and policies, preparing good quality service delivery, and strengthening partnerships by implementing the Human Capital program. In other words, good governance encompasses the advancement of management in all social aspects. The implementation of good governance principles is important to improve the efficiency and effectiveness of public administration.

Lin, Lee, and Tai (2012) stated that human resource approaches contribute substantial and positive effects on market access capabilities, integrity-associated competencies, and functionality-associated competencies. Nazlina (2011) mentioned that SMEs should focus on HRM practices to facilitate the achievement of organizational goals, improve integrity, and generate innovations.

\subsection{Infrastructure and Facilities}

A fundamental part of infrastructure encourages the standardization of services, improvement, and interoperability (Landsbergen and Wolken, 2001), which improve control, operation, and reduce maintenance expenses (Kaplan, 2005). E-government is also enhanced (Janssen et al., 2009). Regardless of ownership, good governance plays a major role in infrastructural development (Akanbi, 2013). The significance of good governance was emphasized in the World Development Report on infrastructure, which described a variety of issues, including both public and private roles of laws and regulations and the management of state-owned enterprises.

\section{Methodology}

\subsection{Sampling and Data Collection}

Data for the study were collected based on a representative survey from the 682 departments and agencies under 24 federal ministries, including the Prime Minister Department in Malaysia. The rate of response of the targeted group to the actual sample was $16 \%$. A total of 109 respondents from 682 target persons replied to the email questionnaire. Previous studies had their rate of responses at 5\% to $10 \%$ (Alreck \& Settle, 1995). A questionnaire was distributed by email and using the Google Doc application to department heads, with assurance of information confidentiality. The email addresses of the respondents were collected from the website of their respective ministries. To ensure high successful response rates, follow up email reminders were sent, as suggested by previous studies (Fan \& Yan, 2010; Kaplowitz, Hadlock, \& Levine, 2004).

\subsection{Measurements of Variables}


Nine factors were used to measure good governance practices, with each factor having several assessment parameters. The list of the items/parameters is given below. Variables were adopted, with some modifications, from the Corporate Integrity Assessment Questionnaire (CIAQ), which was developed by the Malaysian Institute of Integrity (2012). The questionnaire uses a seven-point Likert rating scale, with 1 (strongly disagree) to 7 (strongly agree).

\section{Strategic Alliance (SA) in the public sector of Malaysia}

SA1 Members in the top management in my department have been working effectively.

SA2 My department can distinguish between governance and management.

SA3 My department can measure the performance of the top management.

\section{Strategic Planning (SP) in the public sector of Malaysia}

SP1 My department has global trends in planning and decision making.

SP2 My department achieves balance between sectoral administration and business issues.

SP3 My department has a clear and agreed distinction between strategy and operation.

Risk Management (RM) System in the public sector of Malaysia

RM1 My department considers strategic and specific issue risk.

RM2 My department monitors government priorities.

RM3 My department focuses mostly on the drivers of organizational success.

RM4 My department is up-to-date with international developments/ technology.

RM5 My department ensures that succession planning is conducted.

Audit (AU) in the public sector of Malaysia

AU1 My department appoints an internal auditor and monitors his/her thoroughness in his/her work.

AU2 My department is satisfied with the diligence of the audit/finance committee.

AU3 My department ensures that audit reports are timely and clear.

AU4 My department spends sufficient time in meetings in which actions to audit findings are considered.

Fraud Control (FC) in the public sector of Malaysia

FC1 My department maintains independence and challenges senior management.

FC2 My department ensures that internal control exists to minimize the risk of fraud.

FC3 My department insists on reference checks during employee recruitment.

FC4 My department ensures that internal and external audit processes cover fraud prevention.

FC5 My department has a thorough process in investigating and handling fraud.

Quality Performance $(Q P)$ in the public sector of Malaysia

QP1 My department has a sound system of monitoring program/service quality.

QP2 My department enhances the commitment of all internal people to exhibit quality performance.

QP3 My department ensures that managers are exposed to good practices outside the sector. 
QP4 My department provides training and education for top management and staff.

QP5 My department considers the implications of relevant government legislation.

Financial Resourcing (FR) in the public sector of Malaysia

FR1 My department measures the level of relevant up-to-date services of an organization.

FR2 My department insists on thorough and professional approaches to new businesses.

FR3 My department practices good forecasting, and performance management system exists.

FR4 My department has a reliable system and effectively performs descriptive reporting.

FR5 My department has a conservative approach to risks.

Human Resource Management (HRM) in the public sector of Malaysia

HRM1 My department has a professional human resource plan.

HRM2 My department encourages the involvement of employees in planning.

HRM3 My department complies with modern workplace requirements.

HRM4 My department ensures the presence and value of staff development programs.

HRM5 My department ensures the accountability of performance at all levels.

\section{Infrastructure and Facilities (IF) in the public sector of Malaysia}

IF1 My department monitors the competitiveness of buildings and equipment.

IF2 My department sees that maintenance management is planned.

IF3 My department plans for asset replacement financing.

IF4 My department complies with occupation, health, and safety management.

IF5 My department has an up-to-date registry of assets.

\subsection{Analysis of Data}

Data were analyzed by descriptive statistics and path modeling. Descriptive statistics detailed the general features of the data. Path modeling showed the intensity of the effect of individual factors on the overall measurement of good governance. For the data analysis, we used Excel, SPSS, and Smart PLS software.

For path modeling, we implemented a nonparametric bootstrap procedure to test the significance of coefficients. The PLS path modeling method is advantageous for non-normal data, small sample sizes, formative indicators, complex models, and other common modeling conditions that present challenges for covariance-based methods. Variance-based structural equation modeling can be regarded as a multivariate extension of the ordinary least squares (OLS) regression. The iterative algorithm conducted in PLS consists of a series of OLS analyses (Chin, 1998).

The PLS path modeling methodology includes reflective and formative computations based on the measurement of latent variables. Formative measurement models are used when an explanatory combination of indicator variables underlies the latent construct. These models can best be used when the items describe and define the construct rather than vice versa (Diamantopoulos 2006; Petter et al. 2007). In a formative measurement model, indicators represent the (potentially) independent causes of the latent construct and thus do not necessarily have high correlation. Furthermore, formative indicators are assumed to be error- 
free (Edwards and Bagozzi, 2000). The present study followed the formative measurement model while the path modeling is developed.

The validity of data was tested by checking the normality of data through Skewness and Kurtosis tests, and the reliability of the data and path modeling was tested through internal consistency reliability, indicator reliability, convergent validity, and discriminant validity tests.

\section{Findings and Discussions}

\subsection{Descriptive Analysis}

The present study measured good governance practices in the public sector using 40 indicators under 9 variables. Approximately $75 \%$ of the total respondents agreed that they practiced different good governance factors except for fraud control, which was agreed upon by $66 \%$ of the respondents (Table 1). Among different good governance practice factors, $81 \%$ practiced risk management, which was the highest. However, based on the intensity level of practice of each variable, the highest mean score was found in the audit and financial resourcing, and lowest score was found in the fraud control variable.

Table 1: Survey score on the factors of good governance practices in the public sector of Malaysia

\begin{tabular}{ccccccc}
\hline Variables & $\begin{array}{c}\text { Disagree } \\
\text { (Score 1 to } \\
\text { 3) }\end{array}$ & $\begin{array}{c}\text { Agree (Score } \\
\text { 5 to 7) }\end{array}$ & Mean & $\begin{array}{c}\text { Std. } \\
\text { Deviation }\end{array}$ & Skewness & Kurtosis \\
\hline SA & $10(8.9 \%)$ & $85(77.7 \%)$ & 5.30 & 1.03 & -0.80 & 0.76 \\
SP & $7(6.7 \%)$ & $86(78.9 \%)$ & 5.36 & 0.96 & -0.34 & 0.23 \\
RM & $8(7.7 \%)$ & $88(81.1 \%)$ & 5.41 & 1.00 & -1.32 & 3.81 \\
AU & $8(6.9 \%)$ & $85(77.8 \%)$ & 5.45 & 1.04 & -0.64 & -0.08 \\
FC & $13(11.7 \%)$ & $72(66.2 \%)$ & 5.07 & 1.11 & -0.46 & -0.34 \\
QP & $7(6.8 \%)$ & $85(78.3 \%)$ & 5.44 & 0.93 & -0.59 & 0.21 \\
FR & $6(5.7 \%)$ & $88(80.6 \%)$ & 5.45 & 1.00 & -0.68 & 0.85 \\
HRM & $10(8.8 \%)$ & $86(79.1 \%)$ & 5.36 & 1.07 & -1.11 & 1.61 \\
IF & $13(11.6 \%)$ & $82(74.9 \%)$ & 5.28 & 1.13 & -0.84 & 0.45 \\
\hline
\end{tabular}

Note: percentage of respondents are given in the parenthesis

The highest mean score was 5.45 for audit and financial resourcing factors, and the lowest mean score was 5.07 for fraud control (Table 1). The overall average score for the highest and lowest means is at 5.23, which indicates on an average the respondents are between 'somewhat agree' and 'agree'.

\subsection{Path Modeling Analysis}

Path modeling showed that all factors are significant to the measurement of good governance practices in the public sector (Table 2). The path coefficients indicated a 100-point change from the strategic alliance (SA), and strategic planning (SP) practices will contribute to a point change of 7.8 to 8.5 in the overall good governance practice system (Figure 1). Based on the factors of audit practices (AU), risk management (RM), and quality performance (QP), the changes on the overall good governance practice system are from 11.9 to 13.6 points. The 100-point change in fraud control (FC), human resource management (HRM), and infrastructure and facilities (IF) has brought a change of 14.5 to 15.2 points on the overall good governance practice system. The financial resourcing (FR) factor has the highest effect on the overall the good governance practice system, at 16.4 points for the 100 points change. 
Table 2: Path Coefficient and Total Effect of Path Modeling

\begin{tabular}{cccccc}
\hline $\begin{array}{c}\text { Path } \\
\text { Direction }\end{array}$ & $\begin{array}{c}\text { Original } \\
\text { Sample } \\
(\mathbf{O})\end{array}$ & $\begin{array}{c}\text { Sample } \\
\text { Mean } \\
(\mathbf{M})\end{array}$ & $\begin{array}{c}\text { Standard } \\
\text { Deviation } \\
\text { (STDEV) }\end{array}$ & $\begin{array}{c}\text { Standard } \\
\text { Error } \\
\text { (STERR) }\end{array}$ & $\begin{array}{c}\text { T Statistics } \\
(\mid \mathbf{O} / \text { STERR|) }\end{array}$ \\
\hline SA -> GG & $0.085^{*}$ & 0.084 & 0.008 & 0.008 & 10.338 \\
SP -> GG & $0.078^{*}$ & 0.078 & 0.007 & 0.007 & 10.563 \\
RM -> GG & $0.136^{*}$ & 0.135 & 0.010 & 0.010 & 14.205 \\
AU -> GG & $0.119^{*}$ & 0.119 & 0.006 & 0.006 & 19.151 \\
FC -> GG & $0.145^{*}$ & 0.145 & 0.007 & 0.007 & 19.815 \\
QP -> GG & $0.136^{*}$ & 0.135 & 0.007 & 0.007 & 19.354 \\
FR -> GG & $0.164^{*}$ & 0.164 & 0.008 & 0.008 & 20.568 \\
HRM -> GG & $0.150^{*}$ & 0.149 & 0.009 & 0.009 & 16.798 \\
IF -> GG & $0.152^{*}$ & 0.151 & 0.008 & 0.008 & 18.202 \\
\hline
\end{tabular}

* significant at $1 \%$ level.

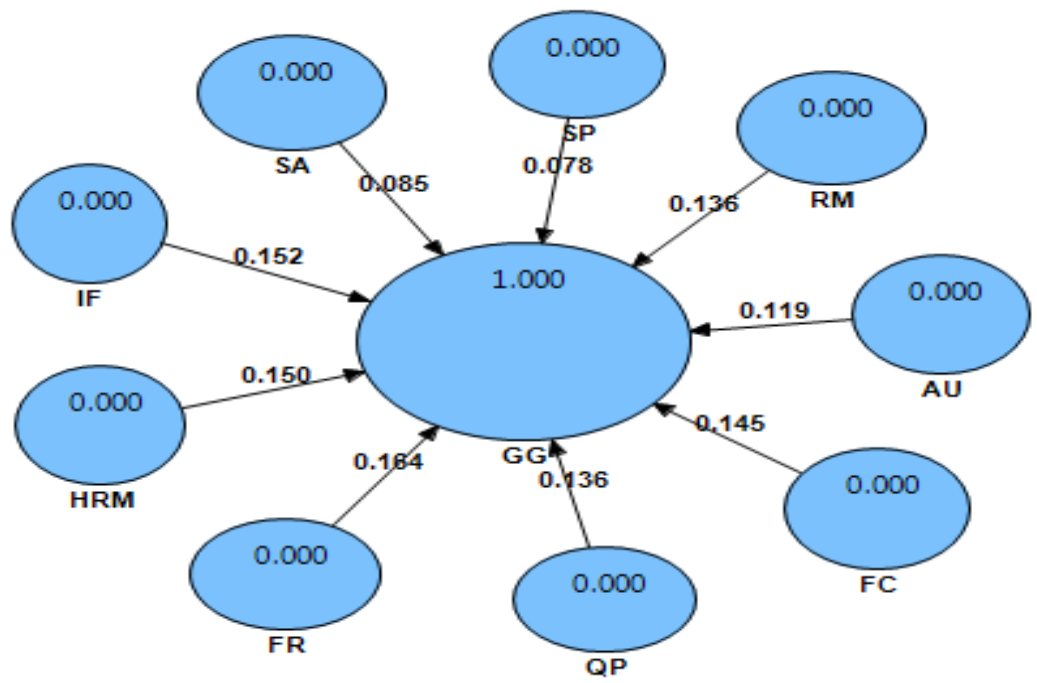

Figure 1: Path diagram for the good governance measurement model

\subsection{Diagnostic Test}

4.3.1 Normality Test

We used skewness and kurtosis to test the assumption of normal distribution. To assume that the data were normally distributed, skewness was set within the range of +1 and -1 , and the Kurtosis value was set from +3 to -3 or from +2 to -2 (Field, 2009). Results showed the value of skewness for all variables in the range of +2 to -2 , and the value of Kurtosis was between +3 and -3 , except for the risk management variable. Therefore, the data were assumed to be normally distributed.

\subsubsection{Reliability Test}

Internal Consistency Reliability: Internal consistency reliability was observed between all constructs, with the composite reliability of more than 0.7 for all constructs (Table 3).

Table 3: Composite Reliability and Convergent Validity (Average Variance Extracted- AVE)

\begin{tabular}{ccccccc}
\hline $\begin{array}{c}\text { Latent } \\
\text { Variable }\end{array}$ & AVE & $\begin{array}{c}\text { Composite } \\
\text { Reliability }\end{array}$ & $\begin{array}{c}\text { R } \\
\text { Square }\end{array}$ & $\begin{array}{c}\text { Cronbachs } \\
\text { Alpha }\end{array}$ & Communality & Redundancy \\
\hline SA & 0.7666 & 0.9079 & & 0.8482 & 0.7666 & \\
SP & 0.7038 & 0.8768 & 1 & 0.789 & 0.7038 & 0.0979 \\
RM & 0.6768 & 0.9128 & & 0.8804 & 0.6768 & \\
AU & 0.7913 & 0.9381 & & 0.9118 & 0.7913 & \\
& & & & &
\end{tabular}




\begin{tabular}{ccccc} 
FC & 0.7254 & 0.9291 & 0.9037 & 0.7254 \\
QP & 0.655 & 0.9046 & 0.868 & 0.655 \\
FR & 0.7916 & 0.9499 & 0.9337 & 0.7916 \\
HRM & 0.7546 & 0.9388 & 0.9185 & 0.7546 \\
IF & 0.7798 & 0.9465 & 0.9292 & 0.7798 \\
GG & 0.5424 & 0.9792 & 0.978 & 0.5424 \\
\hline
\end{tabular}

Convergent Validity: Average Variance Extracted (AVE) of more than 0.5 for all of the constructs indicates convergent validity between all the constructs (Table 3 ).

Discriminant Validity: Comparison between the cross loading and outer loading in Table 7 indicates that the loading of indicators using their own construct is higher than other constructs having cross loadings. The results reflect discriminant validity between all the constructs based on the cross loading criterion.

Table 4: Outer Loading and Cross Loading of the Path Model

\begin{tabular}{|c|c|c|c|c|c|c|c|c|c|c|c|c|}
\hline \multirow{2}{*}{ Indicators } & \multicolumn{10}{|c|}{ Cross Loading (Original Mean) } & \multirow{2}{*}{$\begin{array}{l}\text { Outer } \\
\text { loading }\end{array}$} & \multirow{2}{*}{$\begin{array}{c}\text { T Statistics } \\
(|\mathrm{O} / \mathrm{STERR}|)\end{array}$} \\
\hline & SA & SP & RM & $\mathrm{AU}$ & $\mathrm{FC}$ & QP & FR & HRM & IF & GG & & \\
\hline SA1 & 0.89 & 0.72 & 0.70 & 0.59 & 0.63 & 0.63 & 0.62 & 0.60 & 0.54 & 0.75 & 0.89 & 43.9188 \\
\hline SA2 & 0.87 & 0.59 & 0.56 & 0.51 & 0.53 & 0.51 & 0.47 & 0.48 & 0.52 & 0.63 & 0.87 & 24.5827 \\
\hline SA3 & 0.87 & 0.72 & 0.61 & 0.60 & 0.65 & 0.59 & 0.58 & 0.52 & 0.55 & 0.72 & 0.72 & 26.0836 \\
\hline SP1 & 0.68 & 0.80 & 0.60 & 0.52 & 0.56 & 0.47 & 0.45 & 0.47 & 0.39 & 0.61 & 0.80 & 17.3373 \\
\hline SP2 & 0.70 & 0.89 & 0.64 & 0.61 & 0.64 & 0.59 & 0.58 & 0.58 & 0.57 & 0.73 & 0.89 & 37.1544 \\
\hline SP3 & 0.57 & 0.83 & 0.63 & 0.41 & 0.53 & 0.54 & 0.66 & 0.60 & 0.54 & 0.68 & 0.83 & 20.5002 \\
\hline RM1 & 0.61 & 0.69 & 0.83 & 0.56 & 0.58 & 0.57 & 0.62 & 0.67 & 0.55 & 0.73 & 0.83 & 17.9875 \\
\hline RM2 & 0.53 & 0.61 & 0.81 & 0.51 & 0.59 & 0.61 & 0.63 & 0.50 & 0.45 & 0.68 & 0.81 & 15.9252 \\
\hline RM3 & 0.61 & 0.54 & 0.86 & 0.56 & 0.55 & 0.69 & 0.63 & 0.52 & 0.51 & 0.71 & 0.86 & 23.1229 \\
\hline RM4 & 0.60 & 0.63 & 0.81 & 0.60 & 0.60 & 0.63 & 0.66 & 0.61 & 0.52 & 0.73 & 0.81 & 15.668 \\
\hline RM5 & 0.60 & 0.58 & 0.80 & 0.74 & 0.71 & 0.61 & 0.61 & 0.49 & 0.53 & 0.73 & 0.80 & 16.7021 \\
\hline AU1 & 0.64 & 0.61 & 0.71 & 0.91 & 0.72 & 0.69 & 0.58 & 0.52 & 0.61 & 0.77 & 0.91 & 45.7578 \\
\hline AU2 & 0.58 & 0.53 & 0.63 & 0.91 & 0.74 & 0.65 & 0.54 & 0.46 & 0.58 & 0.73 & 0.91 & 41.8996 \\
\hline AU3 & 0.57 & 0.52 & 0.66 & 0.90 & 0.70 & 0.66 & 0.59 & 0.53 & 0.62 & 0.75 & 0.90 & 31.5743 \\
\hline AU4 & 0.52 & 0.52 & 0.58 & 0.84 & 0.57 & 0.60 & 0.50 & 0.48 & 0.52 & 0.66 & 0.84 & 19.1846 \\
\hline $\mathrm{FC} 1$ & 0.64 & 0.62 & 0.65 & 0.67 & 0.86 & 0.63 & 0.56 & 0.49 & 0.61 & 0.74 & 0.86 & 34.4656 \\
\hline FC2 & 0.40 & 0.36 & 0.43 & 0.52 & 0.70 & 0.54 & 0.39 & 0.30 & 0.40 & 0.53 & 0.70 & 8.5526 \\
\hline FC3 & 0.70 & 0.75 & 0.76 & 0.69 & 0.89 & 0.73 & 0.70 & 0.67 & 0.64 & 0.84 & 0.89 & 38.6728 \\
\hline FC4 & 0.55 & 0.56 & 0.62 & 0.67 & 0.89 & 0.75 & 0.63 & 0.60 & 0.63 & 0.77 & 0.89 & 30.3587 \\
\hline FC5 & 0.62 & 0.59 & 0.64 & 0.71 & 0.90 & 0.74 & 0.68 & 0.56 & 0.56 & 0.78 & 0.90 & 49.8887 \\
\hline QP1 & 0.52 & 0.51 & 0.59 & 0.60 & 0.73 & 0.77 & 0.58 & 0.49 & 0.52 & 0.69 & 0.77 & 19.3626 \\
\hline QP2 & 0.55 & 0.50 & 0.65 & 0.66 & 0.75 & 0.83 & 0.63 & 0.49 & 0.53 & 0.73 & 0.83 & 21.8841 \\
\hline QP3 & 0.59 & 0.61 & 0.63 & 0.57 & 0.63 & 0.80 & 0.72 & 0.64 & 0.54 & 0.75 & 0.80 & 17.8434 \\
\hline QP4 & 0.54 & 0.53 & 0.63 & 0.55 & 0.58 & 0.84 & 0.67 & 0.70 & 0.66 & 0.75 & 0.84 & 21.4398 \\
\hline QP5 & 0.45 & 0.43 & 0.56 & 0.59 & 0.57 & 0.80 & 0.70 & 0.65 & 0.61 & 0.71 & 0.80 & 15.8948 \\
\hline FR1 & 0.51 & 0.55 & 0.64 & 0.56 & 0.66 & 0.80 & 0.89 & 0.76 & 0.69 & 0.81 & 0.89 & 32.7987 \\
\hline FR2 & 0.61 & 0.61 & 0.72 & 0.52 & 0.63 & 0.71 & 0.89 & 0.70 & 0.62 & 0.79 & 0.89 & 34.6537 \\
\hline FR3 & 0.61 & 0.64 & 0.74 & 0.64 & 0.69 & 0.77 & 0.91 & 0.79 & 0.69 & 0.86 & 0.91 & 50.4726 \\
\hline FR4 & 0.65 & 0.63 & 0.71 & 0.61 & 0.69 & 0.76 & 0.94 & 0.76 & 0.69 & 0.85 & 0.94 & 60.9343 \\
\hline FR5 & 0.46 & 0.58 & 0.58 & 0.42 & 0.46 & 0.57 & 0.82 & 0.77 & 0.55 & 0.69 & 0.82 & 18.7568 \\
\hline HRM1 & 0.37 & 0.44 & 0.53 & 0.38 & 0.45 & 0.56 & 0.74 & 0.83 & 0.59 & 0.66 & 0.83 & 17.4922 \\
\hline HRM2 & 0.49 & 0.56 & 0.52 & 0.38 & 0.53 & 0.59 & 0.71 & 0.84 & 0.53 & 0.68 & 0.84 & 21.0452 \\
\hline HRM3 & 0.60 & 0.61 & 0.67 & 0.50 & 0.59 & 0.66 & 0.79 & 0.91 & 0.72 & 0.80 & 0.91 & 48.2452 \\
\hline HRM4 & 0.57 & 0.63 & 0.62 & 0.58 & 0.57 & 0.65 & 0.70 & 0.90 & 0.74 & 0.78 & 0.90 & 42.9937 \\
\hline HRM5 & 0.61 & 0.60 & 0.60 & 0.56 & 0.59 & 0.71 & 0.73 & 0.87 & 0.81 & 0.80 & 0.87 & 26.898 \\
\hline
\end{tabular}




\begin{tabular}{llllllllllllc} 
IF1 & 0.56 & 0.61 & 0.59 & 0.58 & 0.59 & 0.65 & 0.65 & 0.75 & $\mathbf{0 . 8 4}$ & 0.76 & 0.84 & 22.4413 \\
IF2 & 0.55 & 0.52 & 0.45 & 0.53 & 0.58 & 0.56 & 0.59 & 0.68 & $\mathbf{0 . 8 7}$ & 0.70 & 0.87 & 27.5144 \\
IF3 & 0.56 & 0.54 & 0.52 & 0.63 & 0.59 & 0.64 & 0.71 & 0.73 & $\mathbf{0 . 9 2}$ & 0.77 & 0.92 & 54.288 \\
IF4 & 0.44 & 0.43 & 0.54 & 0.57 & 0.59 & 0.62 & 0.59 & 0.62 & $\mathbf{0 . 8 7}$ & 0.70 & 0.87 & 30.3365 \\
IF5 & 0.58 & 0.53 & 0.64 & 0.59 & 0.63 & 0.64 & 0.68 & 0.70 & $\mathbf{0 . 9 1}$ & 0.78 & 0.91 & 52.5168 \\
\hline
\end{tabular}

*Bold data indicate the loading of the indicator on its own construct

Indicator Reliability: The model exhibits indicator reliability, with outer loadings of all indicators as higher than 0.7 (Table 4). The t-stat for all the indicators was significant at 1\%, indicating that all indicators are appropriate for measuring good governance practices in the public sector of Malaysia.

\section{Conclusions and Recommendations}

Malaysia aims to achieve Vision 2020 to become a developed nation. However, many steps should be taken to improve the good governance system of the public sector and then to achieve the previously mentioned program. This study measured the status of current good governance practices in the public sector by assessing nine factors. Among these factors, risk management is practiced by the most number of people, whereas only a few implemented fraud control. Based on the intensity level of the practices of each variable, the highest mean score was found for the audit and financial resourcing variables, whereas and lowest score was found in the fraud control variable. Among the service groups, the engineer group was the highest in the practice of good governance, whereas the health service group demonstrated the lowest level. Based on the structural equation model, we found that all nine factors were significant in the measurement good governance practices in the public sector.

In conclusion, fraud control is least practiced in the public sector of Malaysia. Thus, the level of corruption in Malaysia remains high, with most strategies and current campaigns having no significant effects in containing and fighting corruption (Siddiquee, 2009). The Asia Pacific Fraud Survey Report Series 2013 reported that Malaysia, together with China, has the highest level of bribery and corruption cases. Another survey by the Transparency International on Corruption Perceptions Index (CPI) 2013 showed that Malaysia has increased by one slot in the rankings, that is, from 54 to 53 out of 177 countries with a score of 50, but the people remained to have the average range of perception, indicating that graftfighting measures efforts are still inadequate (The Sunday Daily, 2013). Despite government efforts to restore public confidence, more steps must be taken to improve public perception toward public sector accountability.

Simply changing the structure of bureaucracies is not enough to improve the previously described situation. The public sector must be transformed into a reliable and efficient sector by ensuring good governance and implementing a proper assessment system. Enhancement of good governance practices can help achieve the aspirations of stakeholders and ensure accountability of the public sector. Departments and ministries should also exhibit ethics and integrity in activities they organize to cultivate good governance. To educate the public on the significant step taken by the government to reduce misconducts among employees, reports should be made available to the public.

Our findings will help different government agencies and departments to improve their governance system based on relevant service schemes. Factors and techniques for measuring 
good governance in this study may also help the government in developing internal efficiency measurement techniques for the public sector.

\section{References}

Akanbi, O. A. (2013). Does Governance Matter in Infrastructure : Evidence From SubSaharan Africa. International Business \& Economic Research Journal, 12 (1). 113126

Alleyne, P., \& Howard, M. (2004). An exploratory study of auditors' responsibility for fraud detection in Barbados. Managerial Auditing Journal. 20(3):284-303.

Alreck, P. L., \& Settle, R. B. (1995). The survey research handbook (p. 470). New York: McGraw-Hill.

Arnold, M. , Ganesh, K., \& Arnold M. W. (2002). Corporate governance and the audit process. Contemporary Accounting Research. 19(4), 573-594,

Aziz, M.A.A., Rahman, H.A., Alam, M.M., \& Said, J. 2015a. Enhancement of the Accountability of Public Sectors through Integrity System, Internal Control System and Leadership Practices: A Review Study. Procedia Economics and Finance, 28: 163-169.

Aziz, M.A.A., Said, J., \& Alam, M.M. 2015b. An Assessment of the Practices of Leadership Quality in the Public Sectors of Malaysia. Procedia Economics and Finance, 31: 909918.

Aziz, M.A.A., Said, J., \& Alam, M.M. 2015c. Assessment of the Practices of Internal Control System in the Public Sectors of Malaysia. Asia-Pacific Management Accounting Journal, 10(1): 43-62

Baker, G. P., Gibbons, R., \& Murphy, K. J. (2008). Strategic alliances: bridges between 'islands of conscious power. Journal of the Japanese and International Economies, $22(2), 146-63$.

Barney, J. (1991). Firm Resources and Sustained Competitive Advantage. Journal of Management 17, 99-120.

Barret, P. (2007). A Matter of Record: Document Management as Part of Good Corporate Governance, Risk Management and Decision Mkaing. Australian Accounting Review, $17(1), 88$.

Boyd, G. (2005). Social Auditing - A Method of Determining Impact. Retrieved from www.calendoria.org.uk/socialland/social.html

Brush, C., Manolova, T., \& Edelman, L. (2008). Properties of emerging businesses: An empirical test. Journal of Business Venturing, 25, 547-66.

Bu“yu"ko"zkan, G., Feyzioglu, O., \& Nebol, E. (2008). Selection of the strategic alliance partner in logistics value chain. International Journal of Production Economics, 113 (1), 148-158

Cannatelli, B. (2012). The Role of Network Facilitators in Fostering Trust within Strategic Alliances: A Longitudinal Case Study. Journal of Small Business \& Entrepreneurship, 25(1), 19-34

Chin, W.W. (1998), The Partial Least Squares Approach to Structural Equation Modelling, in G.A. Marcoulides [ed.]. Modern Methods for Business Research, 295-336.

Coleman, A. K., \& Osei, K. A. (2008). Outreach and profitability of microfinance institutions: the role of governance. Journal of Economic Studies, 35 (3), 236-248.

Colombo, M.G., \& Piva., E. (2008). Strengths and weaknesses of academic start-ups: A conceptual model. IEEE Transactions on Engineering Management, 55 (1), 37-49.

Demidenko, E., \& McNutt, P. (2010). The ethics of enterprise risk management as a key component of corporate governance. International Journal of Social Economics, $37(10), 802-815$. 
Diamantopoulos, A. 2006. The error term in formative measurement models: interpretation and modeling implications. Journal of Modelling in Management 1(1): 7-17.

Dickson, G., Phelps, S., \& Waugh, D. (2010). Multi-level governance in an international strategic alliance The plight of the Phoenix and the Asian football market. Asia Pacific Journal of Marketing and Logistics, 22(1), 111-124.

Donker, H., \& Zahir, S. (2008). Towards an impartial and effective corporate governance rating system. Corporate Governance: The International Journal of Business in Society, 8(1), 83-93.

Edwards, J.R. \& Bagozzi, R. P. 2000. On the Nature and Direction of Relationships between Constructs and Measures, Psychological Methods 5(2), 155-174.

Fan, W., \& Yan, Z. (2010). Factors affecting response rates of the web survey: A systematic review. Computers in Human Behavior, 26, 132-139.

Ghonkrokta, S. S., \& Lather, A. S. (2007). Identification of Role of Social Audit by Stakeholders as Accountability Tool in Good Governance. Journal of Management Research, 7(1). 18-26

Glaister, K., Husan, R., \& Buckley, P. (2003). Learning to manage international joint ventures, International Business Review 12, 83-108.

Hifzainam, F. A. (2014). Corporate governance and its impact on performance of banking sector in Pakistan. International Journal of Information, Business and Management. 6(3), 106-118.

Iyer, D. (2011). Tying Performance Management to Service Delivery: Public Sector Reform in Malaysia, 2009 - 2011. Innovations for Successful Societies, 1-15.

Janssen, M., Chun, S.A., \& Gil-Garcia, J. R. (2009). Building the Next Generation Digital Government Infrastructures. Government Information Quarterly (26), 233-237.

Jones, O., \& Jayawarna, D. (2010). Resourcing new businesses: social networks, bootstrapping and firm performance. Venture Capital, 12(2), 127-152.

Kaplan, J. (2005). Sorting through software as a service. Network World, Nov 21, 2005

Kaplowitz, M., Hadlock, T., \& Levine, R. (2004). A comparison of web and mail survey response rates. Public Opinion Quarterly, 68, 94-101.

Landsbergen, J. ., \& Wolken, J. . (2001). Realizing the Promise: Government Information Systems and the Fourth Generation of Information Technology. Public Administration Review (61:2), 206-220.

Li, N. (2008). Religion, opportunism, and international market entry via non-equity alliances or joint ventures. Journal of Business Ethics, Vol.80 No., 771-89.

Lichtenstein, B., \& Brush., C. (2001). How do "resource bundles" develop and change in new ventures? A dynamic model and longitudinal exploration. Entrepreneurship Theory and Practice, 25 (3).

Lin, H., Lee, Y., \& Tai, C. (2012). A Study on the Relationship Between Human Resource Management Strategies And Core Competencies. International Journal of Organizational Innovation, 4 (3), 153-174.

Louizi, G. (2006). Les mécanismes internes de gouvernance bancaire: importance et interactions; application aux banques tunisiennes, Working Paper (No. 34p). Retrieved from www.iecs. edu/congres/articles/article-final-louizi.pdf,

Malaysian Institute of Integrity. (2012). A Consultative Document on Corporate Integrity System Assessment Questionnaire: Corporate Integrity Systems Malaysia 2010-2012 A Corporate Integrity Assessment.

Martin, T., Linda, M., Joyce, A., \& Max, W. (2007). A Focus on Integrity: A Dedicated Integrity Unit, Housed Within The Internal Audit Department, Offers Powerful FraudFighting Capabilities and Investigative Resources. Internal Auditor. 
Martinov-Bennie, N. (2007). What We Might Learn About Fraud And Corporate Governance From Nab'S “Annus Horriblis.” Australian Accounting Review, 17(3), 85.

Muzainah, M., \& Mahamad, T. (2012). Strategic Planning in Public Organization: The Case of a Tax Administration in a Developing Country, 1(8), 20-33.

National Audit Department. (2013). Auditor general report 2012. Government of Malaysia.

Ohame, K. (1989). The Global Logic of Startegic Alliance. Harvard Business Review, 143154.

Okpala, K. E. (2012). Audit Committee and Integrity of Financial Statements: A Preventive Mechanism for Corporate Failure. Australian Journal of Business and Management Research, 2(08), 32-40.

Peda, P., Argento, D., \& Grossi, G. (2013). Governance and Performance of a Mixed PublicPrivate Enterprise: An Assessment of a Company in the Estonian Water Sector. Public Organization Review, 13(2), 185-196.

Petter, S., Straub, D. \& Rai, A. 2007. Specifying formative constructs in information systems research, MIS Quarterly, 31(4): 623-656.

Placet M., \& Branch, K. M. (2002), Strategy, ch. 3 in Managing Science as a Public Good: Overseeing Publicly Funded Science, Baker, K.A. (eds.), Available at http://www.au.af.mil/au/awc/awcgate/doe/benchmark/

Rusnah, I., Nazlin Emieza, N., Iskandar Hassan, T. A., Asri, S., Norlaila, I., Norhafizah, A. T., Jusof, K., Sakinah, M. Z. (2011). The Perception of Integrity of Three Public Agencies in Kuala Terengganu, World Applied Sciences Journal, 12, 60-63.

Said, J., Alam, M.M., \& Aziz, M.A. 2015. Public Accountability System: Empirical

Assessment of Public Sector of Malaysia. Asian Journal of Scientific Research, 8(2): 225-236.

Said, J., Alam, M.M., \& Khalid, M. 2016. Relationship between Good Governance and Integrity System: Empirical Study on the Public Sector of Malaysia. Humanomics, 32(2): 151-171.

Siddiquee, N. A. (2006). Public management reform in Malaysia: Recent initiatives and experiences. International Journal of Public Sector Management, 19(4), 339-358.

Siddiquee, N. A. (2009). Combating Corruption and Managing Integrity in Malaysia: A Critical Overview of Recent Strategies and Initiatives. Public Organization Review, 10(2), 153-171.

Silva, L. M. da, \& Neto, J. S. (2014). Method for Measuring the Alignment Between Information Technology Strategic Planning And Actions of Informtion Technology Governance, Journal of Information Systems and Technology Management, 11(1), 131-152.

Subramaniam, N., McManus, L., \& Zhang, J. (2009). Corporate governance, firm characteristics and risk management committee formation in Australian companies. Managerial Auditing Journal, 24(4), 316-339.

Sumpor, M., \& Dokic, I. (2012). Strategic Planning As A Tool For Better Public Policy Governance - The Case of Croatia. The 6th International Conference "An Enterprise Odyssey: Corporate governance and public policy - path to sustainable future", Faculty of Economics and Business, University of Zagreb, Croatia, June 13-16, 2012

Sumpor, M., \& Dokic, I. (2013). Are There Any Improvements In Governance After a Decade of Regional Strategic Planning in Croatia. $10^{\text {th }}$ International Conference Challenges of Europe: The Quest for New Competitiveness. Split, Hrvatska 2013

Teng, B., \& Das, T. K. (2008). Governance structure choice in strategic alliances. Management Decision, 46(5), 725-742. 
The Malaysian Digest. 2014. Wawasan 2020. A Vision Impossible?. Malaysian Digest.Com. Retrieved from http://www.malaysiandigest.com/opinion/487212-wawasan-2020-avision-impossible.html

The Star. (2008). Malaysia still lagging in Corruption Perceptions Index. The Star Publications. Retrieved from http://www.thestar.com.my/story.aspx/?file=/2008/9/24/nation/2100629\&sec=nation

The Sunday Daily. (2013, December 3). M'sia ranks 53 in Corruption Perception Index 2013 (Updated). The Sunday Daily. Retrieved from http://www.thesundaily.my/news/895842

Tie, F. H. (2004). Strategic Tripartite Alliance in Establishing A Safe School Programme in Malaysia. OECD report, 2004

Wiklund, J., \& Shepherd, D. . (2009). The Effectiveness of Alliances and Acquisitions: the Role of Resource Combination Activities. Entrepreneurship: Theory and Practice, 33 (1), 193-212. 